\title{
Predestinasi
}

Volume 14, No. 1, Juni 2020, Hal. 27- 34

ISSN (Print): 1978-9351

\section{Audience Development Strategy in the Theatre}

\author{
Edet Essien \\ Department of Theater Media and Carnival Studies, \\ Faculty of Arts, University of Calabar, Calabar, Nigeria \\ *e-mail: edetessien@yahoo.com
}

\begin{abstract}
The position of arts patrons is that of importance. The audience is the reason why the artist is there. Without their presence, the theatre experience is incomplete. This work examines the different categories of audiences that exist and the audience development strategies often employed. It identifies that the development of audiences for the theatre is prosecuted at two different but related levels; the first focuses on attracting attention to the event while the second gears towards sustaining the interest so generated. These issues are pertinent and vital and should be considered if theatre is to thrive, especially in this era where it is in serious competition with other modes.
\end{abstract}

Keywords: The audience; theatre; theatre business; effective marketing.

\section{INTRODUCTION}

The efficacy and contributions of the arts to human existence defies quantification. The relationship between the two entities is mutual and has been experienced and felt right from the beginning of times till date. This may have propelled the great philosopher, Dante to proclaim that in the middle of the journey of our lives, he found himself in a dark wood. Light is required to penetrate that darkness. Such a light he asserted, can best be found within the realms of the arts and religion. Initially, it was difficult to delineate between art and religion as both were interwoven and a very thin line separated them. Doris Van de Bogart (1971) corroborates this by asserting that when the first medieval universities were established in the 12th and 13th Centuries, the Professors who were predominantly clergies, were interested in arguing about metaphysics and religion. This position was informed by their notion of the arts - made primarily of Latin, Philosophy and Theology (the Classics).

Renaissance scholars extended the arts to include Fine Arts, Music and Literature but by the 19th Century, the arts and religion lost the importance hitherto accorded them as people seemed to embrace and turn to the sciences and social sciences for succour and answers to the perplexities of human existence. Today, the arts have been broadly divided into three categories: Performing Arts, Visual Arts and Literary Arts. Theatre is part of the performing arts. One feature with the arts is that they thrive through patronage. Each work of art has its own patrons. To make meaning, the artwork must have someone to appreciate the aesthetics, the ingenuity and creativity embedded in it. Without this very vital exercise, the work is incomplete and the artist partially satisfied or fulfilled for his endeavour. This may have been responsible for Roman Ingarden's (2001, p. 179) assertion: 
“... Artworks achieve full existence only in someone's reading of them, for the 'work' is more than the material thing, it comprises the meanings and experiences generated by our interpretation of that thing."

From the above, one can see that the position of Arts patrons (in the case of theatre audience) is that of importance. It is based on this that the strategy for Audience development in the theatre becomes an issue and the focus of this work.

\section{THE AUDIENCE}

The audience cannot be ignored particularly as the theatre's major and only target is the audience (Uwaoma 1991; Essien 2005; Essien 2006). It is the better half of the theatre production (Nwamuo, 2003). Audiences have always existed in theatre. First they were worshippers who were part and parcel and actively involved in the unfolding drama as evident in the Greek worship of Dionysus; the god of wine and fertility. The celebrants were not ordinary spectators rather worshippers who went to be involved and show appreciation to the god. This exercise did not stop at the City Dionysia alone in Athens - Greece; it also permeated the festivals in the rural areas.

The Romans equally toed these lines, presenting theatre productions as part of religious festivals. In the early development of the Roman Empire, Etruria was the dominant influence on Roman theatrical activities, although it is difficult to assess the Etruscan contributions fully. Nevertheless, it was probably from Etruria that Rome inherited many features of its religious festivals - the principal occasions on which theatrical performances were given in Rome (Brockett with Hildy 1973). With the disintegration of the Roman Empire came the Middle Ages. This period witnessed the rise of the church as a force to be reckoned with. Hitherto, organized theatrical activities had virtually disappeared in Western Europe. It was not until the early Middle Ages that theatre began a revival. Liturgical and non-liturgical plays sprung up. The plays were initially given within the confines of the church. Later, they were produced outside the church. However, Christian festivals continued, some of which involved processions round the city, with the performers (the city dwellers) being spectators also. The Feast of Fools, Feast of the Boy Bishop, Corpus Christi are some of the festivals celebrated at the time.

With the development and extensive use of the proscenium within the Renaissance, there was a conscious separation of the spectators who are now evolving into audience, from the players. This does not in any way mean that within the previous eras, especially the immediate past, there were no separations. There were, but what is being considered now is the conscious creation of that aesthetic distance which lays credence to the illusion of reality being created on stage and enforces believability on the part of the audience. This trend has continued till date. However, it all depends on the type of theatre stage (building or configuration) being played on. One may wonder why the audience is so important. The answer is not far-fetched. They are the reason why the artist is there. Without their presence, the theatre experience is incomplete. Audiences are part and parcel of the circle or chain. Their absence renders the whole endeavour a non-event. Commenting on the role of the audience in a performance, Soyinka (1990) opines that the audience is an integral part of the whole presentation. They contribute spiritual strength to the protagonist through choric realities, which must first be established through offerings and incantations.

The importance of the audience is further buttressed by Edwin Wilson (1991) when he asserted that at the heart of any theatre experience is the actor-audience relationship. He went on to explain that the immediate, personal exchange between the two entities and the chemistry and 
magic arising therefrom, gives theatre its special quality. Here, the players are constantly alert and can hear laughter, can sense silence and can even feel the tension in the audience. These emotions according to him, impact on the production as the players are bound to react to them within the confines of the production, in order to carry the audience along. From whatever perspective the issue is examined, the audience will still remain that entity, that body which has lend itself to witnessing, learning, experiencing and sharing in the performance presentation (Essien 1997). So who and who make up the audience?

\section{CATEGORIZATION OF AUDIENCES}

Attempting to categorize audiences in the theatre is a difficult task. This stems from the fact that from the beginning of theatre, audiences have always visited the theatre due to their interest and desire to celebrate, share, experience and be enriched by the theatre. Even though individual members of the audience possess different traits, characters, wishes, aspirations, etc., they seem to act as one fold, once they are seated in the theatre. Certain spontaneous responses like laughter, sighing, exclamations are known to come from almost all members of the audience at the same time, in reaction to the actions on stage. As such, it becomes a bit difficult to categorize them, especially where they have all decided to willingly suspend their disbelief

One personality, who engaged in this endeavour, was T. S. Eliot. He was born in America but settled in London and later became a British citizen. Eliot was considered to be a prominent poet but he wrote no complete play until 1934 when he reformed and extended the work of E. Martin Browne. Based upon the success of that experiment, he was commissioned to put together a play for the Canterbury Festival. Eliot produced a masterpiece, Murder in the Cathedral, which was first presented at Canterbury in 1953 and has survived and still relevant till date (Brockett and Finlay, 1999). Though Eliot's visual imagination was weak, his feeling for the dramatic possibilities in music and rhythm was very strong and the idea of fusing all the arts into one complete blend in a production was equally strong for him. He longed for the collaboration between actors and audience and his admiration for the improvising technique of performers showed clearly his dramatic imagination. His love for dance was strong and he was continuously praising the art of ballet (Worth 1986). He was a lover of what may be termed today as total theatre. He made a distinction between audiences and was particularly interested in their satisfaction. That may have been the reason why he was interested in fusing other arts into drama presentations, so as to satisfy the "heterogeneous" audience which he identified, often attend theatre productions.

Another personality who attempted to categorize audiences is Edwin Wilson; the teacher, author and critic. He has worked in many aspects of theatre. Before he became a teacher and a writer, he worked as an Assistant Producer in many films directed by icons in the field. He equally produced several off-Broadway shows and co-produced a Broadway play and was a Resident Director of the Barter Theatre in Virginia (Wilson 1991). Every attempt at compartmentalizing audiences that visit the theatre is based on experience and perception. Being involved in the nonartistic area of production which ultimate aim and objective is guaranteeing satisfaction of the audience and maximizing profits, Edwin Wilson (1991) identified two types of audience General and Homogeneous. General audiences, which can also be called mixed audiences, comprise people of different ages, social standing and works of life. They come from different parts and are drawn to the event by their desire to be educated, informed and entertained and for the purposes of exposure. Producers must be aware of the audience and design their programmes 
to satisfy all the constituents. The second category is Homogeneous audiences. Unlike general audiences, the members here are made up of people within the same age bracket or social standing or endeavour or people drawn together by accident of fate. They often share the same goals, wishes and aspirations in life, at least within the time frame they are together. Wilson (1991) gives examples as spectators at a High School play, a Children's Theatre production, a political play or a performance given in the prison. Producing for this type of audience appears somewhat easier, in the sense that one needs only to identify their own "psychology" and tailor the production towards that line. The reasoning of a particular member of the group is to a large extent, representative of others. But in the case of general audience, it is necessary to identify the various groups that are involved and the production must be directed towards reflecting their various and varied positions.

Another author, Elizabeth Sweeting (1968) also ventured into identifying and categorizing audiences. From here standpoint, a view shared by Nwamuo (2003), there are four types of audiences; they include Target audience, Regular audience, Occasional audience and Potential audience. May I add here, the Unseen audience. Most artistic endeavours are organized and designed for the overall benefit and appreciation of a particular group in the society. This section of the society is the target of such productions; hence they are the target audience. Regular audience refers to that small group of people who are always regular in theatre productions. Whatever happens, they will be there to witness the event, unlike the Occasional audience; present only when there is an event which it deems important or when an important dignitary is visiting the theatre.

Potential audience as the name implies, is made up of people who naturally would come to the theatre but need a little pep talk, a little effort to ginger them up. It could be in form of a telephone call, a note or even a visit. The last but not the least is the unseen audience. They are found predominantly within the Traditional African Theatre and those, which accommodate gods and ancestral worship. It is predicated upon the belief that the gods and ancestors are always present and willing to assist the living. Consequently, they are always present in any theatrical activity and recognized through libations, incantations etc.

\section{AUDIENCE DEVELOPMENT STRATEGIES}

"...Every theatre - from the conventional to the avant-gardist, the didactic to the postmodernist, the traveling to the visited etc., - all need the audience for theatre to "happen" or for the total experience to be realized." (Johnson, 2001, p. 215).

The above assertion further lays credence to the importance of the audience in the theatre experience. The pertinent question at this juncture is how do we get the audience into the theatre? Do they just happen to be there or are there certain measures to be taken to compel or cajole them into watching the production? The answer here is yes. The audience must be created, cultivated and nurtured. In the text, Play Production Processes Effiong Johnson (2001) identifies the various avenues or strategies of getting the audience aware of a theatre production to include Posters, Handbills, Billboards, Banners, Radio and Television commercials and Newspaper preview/reviews. This is primarily the function or role of publicity in the theatre.

The development of audiences for the theatre is prosecuted at two different but related levels. The first, which is mentioned above, aims at attracting the attention of members of the public and gingering their interest in theatre events. The sustenance of that interest is executed at 
the second level. But this very important aspect of audience development is often neglected. Let us examine in detail the constituents of both levels. Once it is appropriate, the manager in consultation with the production director gives the go ahead for campaign materials to be injected into the public. Posters, which are graphic forms of communication carry brief but detailed information about the production. To actually fulfill their intended functions, posters and banners must be simple, attractive, well proportioned, suitable for display, economical and informative (Nwamuo 2003).

Handbills do complement the efforts of other forms of publicity. Unlike some other campaign materials, they are often carried home. One of the strongest points of the handbill is that in the home, it has a way of reminding the would-be audience member and his household of the theatre event, even though it may be lying lazily about. The popularity of the radio and television is ever increasing. The vast listenership and viewership they command respectively, make them potent and functional avenues of publicity in many endeavours including the quest for theatre audiences. Publicity through these media often creates much anxiety and excitement in the minds of the public, especially when they are well crafted and artistically designed to appeal. The same aura is exuded by the Newspaper preview/review, which normally present the making of the event in pictorial forms with a roll call of the personalities involved. Outside these, the direct mail and some forms of novelty publicity like carnival floats are often explored.

As earlier stated, all the above are basically to make the public aware of the theatre production and to move them to attend. The second aspect carries out the bulk of the work of sustaining the captured audience. No theatre outfit worth its salt should neglect this aspect. Assuming that an excellent job was done by way of publicity, as such many people are aware of the production and are willing to attend and they actually do witness it. How do we ensure that they keep attending productions? The second phase of audience development has this function to carry out. There is nothing as devastating in the theatre as audience's dissatisfaction. Every audience member who decides to attend a theatre production expects to get his money's worth. When this aspiration or wish is not met, a terrible blow has been done to the theatre because that audience member may not repeat and may even discourage others from even venturing into the theatre. So, as far as the audience is concerned, there is no second chance for theatre to make a first impression. As such, exposing the audience to good, quality presentations is one of the ways to develop audiences for the theatre (Yta \& Umukoro 2016).

The provision of audience catering services is an essential aspect of theatre administration even though it is often neglected. The notion of audience catering is predicated upon the fact that members of the audience have forsaken other activities that are in competition with theatre, to attend. Some even missed their dinner and so must be adequately compensated. Audience catering involves the provision of those services, which will make the audience member at home and relaxed, as a prelude to enjoying the performance. They include the provision of concessions, good parking spaces, snack bars, in-door games, music and security services (Essien 1994). Conveniences, free stage-bills, theatre programmes or brochures are still part of audience catering. An audience member who is well catered to and feels at home in the theatre, may want to repeat and may even woo others to join him and discover how wonderful an experience theatre-going is.

Many regular and potential audiences find it difficult to visit the theatre or other venues for theatre performances due to fears of violence, coupled with the increasing rate of crimes and armed robbery. Even on university campuses, secret cult activities have curtailed patronage, which hitherto was in a state of boom (Essien 2003; Essien 2014; Essien 2015). The situation is made worse by the stiff competition existing between theatre and home video presently. People 


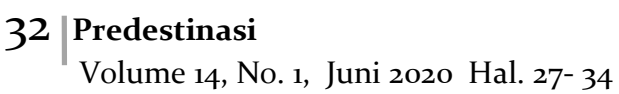

prefer to stay under the covers of their rooms and watch home video films than risk their lives to attend theatre shows.

The provision of security to, within and from the venues of performance is one avenue of reducing security risks and sustaining audiences. One may wonder how possible this would be. The churches have adopted it successfully. It will require creating designated points where audience members can gather and be transported to the show and at the end of the presentation, dropped there too. This will entail some additional costs. However, in the long run, it will pay off. Johnson (2001) believes that since the audience is so important, every possible arrangement, which can draw them to the theatre in an appreciable size, stands recommended and should be undertaken.

\section{CONCLUSION}

A theatre outfit able to lure a sizeable chunk of the audience to its show can rightly be called a thriving theatre. Without this, the theatre is counted among those in the other side of the divide. One of the desires of artists in the theatre is to have a good audience and part of the parameters of determining a good audience is size (Johnson, 2001). It is important to embark on audience research projects if the sizes of our audiences are to increase steadily or maintained. Prince Gondo (2002) advocates studies into audience behaviour as a prelude to effective marketing of theatre productions.

Theatre business is today suffering from lack of patronage due predominantly to the difficult economic environment and stiff competition by the emergent home video industry. But with proper audience development strategies particularly the ones presented in this work, the trend could gradually be reversed. One might argue that the economic situation may constitute impediments. True. But if the right attitudes are inculcated, especially theatre going culture, it can be achieved. The public needs to know also the benefits and experience gathered in attending a live theatre performance. It can never compare to watching a video film at home. Audience development issues are very pertinent and vital. They must be considered if theatre is to thrive. No matter how expertly crafted the script is, no matter how beautifully executed it is, by the artists and designers, no matter how exciting the overall production is; without the audience to witness it, it is a non-event. In developing our audiences, we need not stop at mere publicity. We need to explore the avenues, which make the audience addicted to the theatre. The ideas put forward in this work, will be useful.

\section{REFERENCES}

Bogart, D. V. (1971). Introduction to the humanities: Painting, sculpture, architecture, music, and literature. New York: Barnes \& Noble.

Brockett, O. G., \& Findlay, R. R. (1973). Century of Innovation: A History of European and American Theatre and Drama Since, Prentice-Hall.

Brockett, O. G., \& Hildy, F. J. (1999). History of the theatre. Boston: Pearson Education.

Effiong, J. (2001). Play Production Processes. Lagos: Concept Publications Limited.

Essien, E. (1994). A Survey of Audience Catering Services in the Nigerian Theatre, in Chris Nwamuo (ed.) Focus on Theatre. Calabar: Median Communications. 
Essien, E. (2003). The Performing Artist and Marking Problems in Nigeria. Theatre Studies Review, 3(1).

Essien, E. (2005). The Theatre Administrator and Conflict Resolution in the Theatre. Nduñode, $6(2), 21-28$.

Essien, E. (2006). Audience Development Strategy in the Theatre. An Encyclopaedia of the Arts II.1, 42-50.

Essien, E. (2014). Budgeting and Performing Arts Management in Nigeria: Valuated Concerns. Lwati: A Journal of Contemporary Research, 11(4), 121-130.

ESSIEN, E. (2015). Exploring Theatre For Development (TFL) Praxis In An. Journal of Integrative Humanism Vol. 5 No. 1, 41.

Gondo, P. E. (2002). Marketing the Nigerian Theatre. Makurdi: St. Kalemba Educational Marketing.

Ingarden, R. (2001). Performance Analysis: An Introductory Coursebook. London: Routledge.

Inyang, M. J. P., Alegu, J. C., \& Maku, B. S. (2020). Development Communication Process and Theories: An Overview. GNOSI: An Interdisciplinary Journal of Human Theory and Praxis, 3(1), 61-75.

Nwamuo, C. (2003). Essentials of Theatre Administration. Calabar: University of Calabar Press. Soyinka, W. (1990). Myth, literature and the African world. Cambridge University Press.

Sweeting, E. (1968). Theatre Administration. London: Pitman.

Uwaoma, U. (1991). Catering for Studio Theatre Audiences in Eastern States of Nigeria" Unpublished M. A. Thesis, Theatre Arts Department, University of Calabar.

Wilson, E. (1991). The Theatre Experience 5th edition. New York: McGraw-Hill Inc.

Worth, K. (1986). The Irish Drama of Europe from Yeats to Beckett. London: The Athlone Press.

Yta, E. M., \& Umukoro, G. M. Designs in carnival calabar._duñ_de: calabar journal of the humanities, 413. 


\section{Predestinasi}

Volume 14, No. 1, Juni 2020 Hal. 27- 34 